\title{
Agarwood Tree Characteristics based on Different Growing Habitat and Ecophysiological Attributes in the Papuan Tropical Forests
}

\author{
Amilda Auri ${ }^{1,2,}$, Eny Faridah ${ }^{3}$, Sumardi ${ }^{3}$, Suryo Hardiwinoto ${ }^{3}$ \\ ${ }^{1}$ Graduate Program of Forestry Science, Faculty of Forestry, Gadjah Mada University. Yogyakarta, 55281, Indonesia \\ 2 Department of Forestry, Faculty of Forestry, University of Papua. Manokwari, 98314, West Papua, Indonesia \\ ${ }^{3}$ Faculty of Forestry, Gadjah Mada University. Yogyakarta, 55281, Indonesia \\ * Corresponding author. E-mail address: auriamilda@gmail.com
}

\section{ARTICLE HISTORY:}

Received: 9 April 2021

Peer review completed: 14 September 202I Received in revised form: 28 September 2021 Accepted: 6 November 2021

\section{KEYWORDS:}

Abiotic

Agarwood

Association

Lowland tropical forest

Soil characteristics
C 2021 The Author(s). Published by Department of Forestry, Faculty of Agriculture, University of Lampung in collaboration with Indonesia Network for Agroforestry Education (INAFE). This is an open access article under the CC BY-NC license:

https://creativecommons.org/licenses/by$\mathrm{nc} / 4.0 /$

\begin{abstract}
Understanding tropical forest characteristics, including forest derivative products such as agarwood, is pivotal. This study focused on perceiving an ideal habitat of the lowland tropical forest ecosystem of West Papua for agarwood-producing tree species. In further, this study identified a close association of biotic and abiotic characteristics to underpin agarwoodproducing tree growth. Six sites in three different locations were established to ascertain forest composition and the associated insects. Soil samples were collected to analyze their physical and chemical properties using the Kjeldahl, the Walky and Black, and Atomic Absorption Spectrophotometry (AAS). In addition, temperature, relative humidity, and light intensity were measured. The results noticed two agarwood producing species, Gyrinops caudate and Aquilaria sp., found at an altitude of 400402 masl in Manokwari, 200-300 masl in Teluk Wondama, and 167.7 masl in Teluk Bintuni. There were no significant differences in temperature, relative humidity, and light intensity. The soil cation exchange capacity was moderate in Manokwari, but it was low in Teluk Wondama and Teluk Bintuni. Total C-organic content in three research sites was classified as high. However, total $\mathrm{N}$ content in the three research sites was in the moderate category. The ideal habitat for agarwood in the West Papua forest is from the lowlands to the highlands. Environmental conditions that support the growth of agarwood are moderate temperature, high humidity, and moderate light intensity. Soil fertility also affected the natural growth of agarwood trees.
\end{abstract}

\section{Introduction}

Indonesia has been prominent by its diverse richness of biological diversity, in particular floral varieties across the Islands. Floral diversity has been abundantly widespread and represents unique species in different ecosystems and growing habitats (Sayfulloh et al. 2020; Tuck et al. 2016). Tropical forests contain a million variations of plant characteristics, and it has been varied based on the ecological habitat and growing environment (Gallery 2014). The condition revealed the pivotal role of tropical forests in managing forest ecosystems and natural habitat for an ideal growing habitat (Nasi and Frost 2009; Tuck et al. 2016). It turned out that ecological attributes in different landscapes will generate a variety of forest vegetation and tree species either genetically and morphologically. 
Habitat is an ideal living space for growth and development for plants and animals, and it has been providing an absolute realm over time. A suitably decent habitat will subsequently enrich lots of flora, fauna, and organisms to be incorporated and living as well as compete among others. On the flip side, poor habitat is likely to be uninhabitable for plant and forest microorganisms to stay and reproduce. Such circumstances can be caused by less availability of environmental parameters such as light availability, climatic condition, temperature, humidity, and soil nutrients (Irvantia et al. 2014; Tuck et al. 2016). In addition, plants and organisms require modification and adaptation either in their morphological characteristic and genetic change to be more adaptable with habitat, retain productivity, and normal growth. One of the common adaptations in most vegetation is secondary metabolism that produces an essential barrier to address extreme environmental fluctuations and strengthens their pathway in life (Holopainen et al. 2018; Sampaio et al. 2016; Yang et al. 2018).

Papua has a unique land cover and highly resourceful floral and faunal diversity across the forest ecosystem and habitat (Lekitoo et al. 2017). The area has 20,000-25,000 floristic plant species, most of which are endemic (Lekitoo et al. 2017). Hence, it has been considered one of the mega-biodiversity regions globally, which accounted for 54\% of Indonesia's biodiversity. In the matter of the richness of Papuan forest diversity, one of the merchantable forest products that commercially trade is agarwood. Agarwood is one of the preferred timber forest products that has experienced a population decline in natural forests due to uncontrolled exploitation. However, it requires certain circumstances to be normally hosted by a particular fungus for agarwood to occur. Therefore an ideal habitat and descent niche are ultimately needed to retain an existence and underpin the productivity of agarwood. Furthermore, to be produced, agarwood required a highly supportive surrounding environment, including forest structures, vegetation, landscape attributes, and ideal forest microclimate. In terms of plant distribution in Indonesia, Yuliasyah et al. (2003) noticed several potential growth areas such as Borneo, Sumatera, Java, Sulawesi, Moluccas, Nusa Tenggara, and Papua with the dominant tree genera of Aquilaria, Gyrinops, Aetoxylon, and Gonystylus from Thymelaeaceae family (Subasinghe and Hettiarachi 2015). West Papua possesses a unique forest characteristic and ecosystem composition, and one of those is agarwood-producing species that grow naturally over different ecosystems. However, to precisely determine the ideal ecosystem and habitat for the agarwood-hosted plant, the lowland tropical rain forest of West Papua is laborious. Therefore, this research studied the suitable circumstance for agarwoodproducing trees to potentially occur through their ecophysiological characteristics. Understanding these growing attributes will be potential to mimic for developing suitable habitat for plantation intensification since the product has been commercially beneficial.

\section{Materials and Methods}

\subsection{Study Area}

The selection of the field study was conducted through preliminary observation to assess the potential agarwood host plant distribution. Then, in detail, intense discussions among locals and colleagues and finding pertinent references to dig more regarding the plant were impartially undertaken. From these stages, then three areas were purposively chosen for the study. These areas were Teluk Wondama, Teluk Bintuni, and Manokwari districts in West Papua Province, Indonesia (Fig. 1). The three study areas represented different landscape attributes and ecological 
characteristics contributing to the various forest structures and vegetation formations. In addition, these areas have been commonly known for their potential distribution of agarwood and are still dominant forested areas and considered to be dense in forest structure and composition. The study was conducted from July-October 2018.

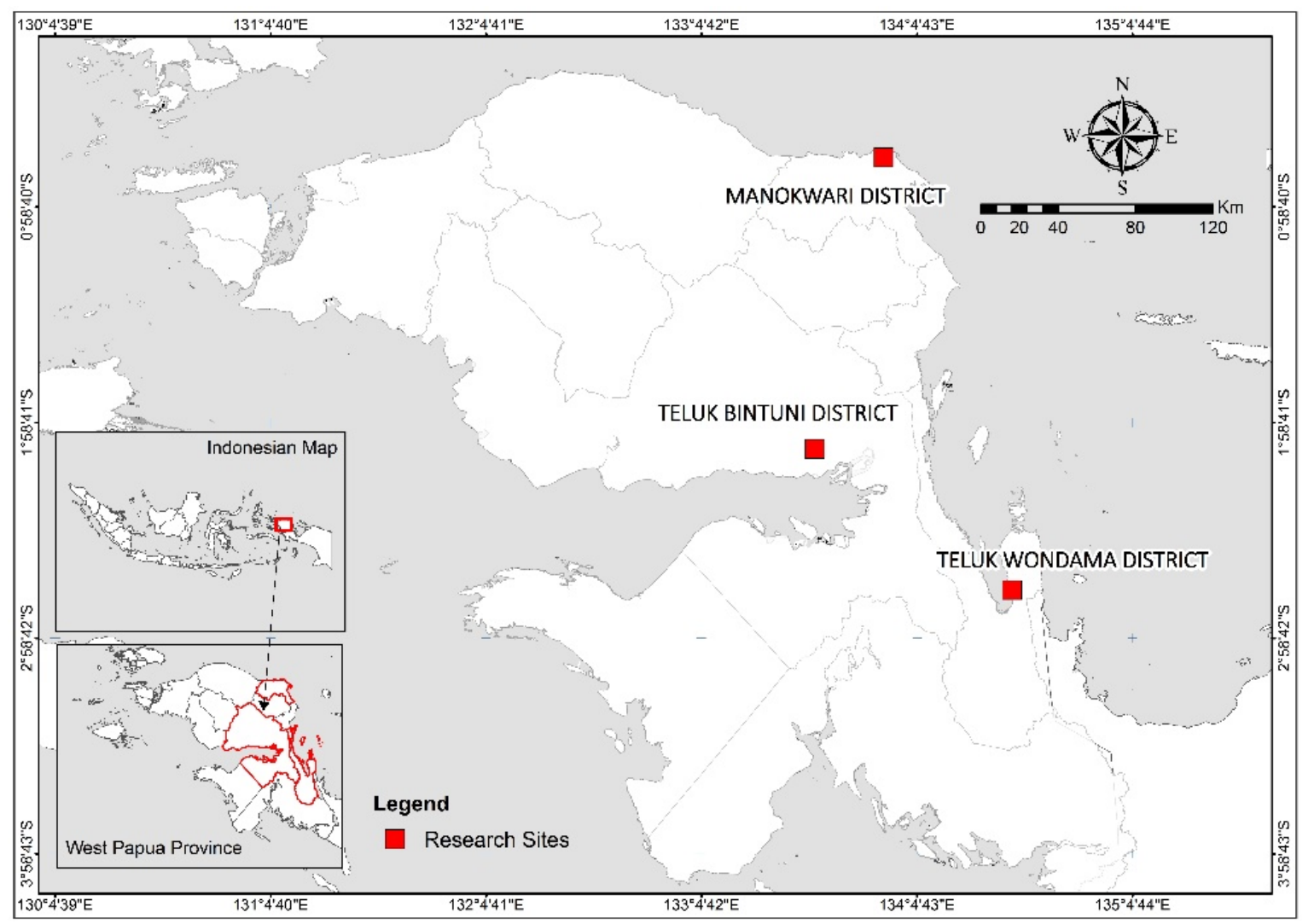

Fig. 1. Map of the research site.

\subsection{Study Design}

This study was primarily focused on a forested area where host plants for agarwood are the potential to come across. It turned out that the three potential study locations were determined based on the occurrence of host plants found from the previous discussions. Therefore, it affects the development of plot design in three research sites. The experimental plots were developed by adjusting to the occurrence of host plants with a minimum of two agarwood producing trees existence. Each experimental plot was square-shaped of $20 \mathrm{~m} \times 20 \mathrm{~m}$ (Nguyen et al. 2015). The taxonomy and morphology of the host trees in conjunction with the occurrence of agarwood were identified. Tree structure and composition were determined by the census for its diameter and branch-free height. Besides, fauna surrounding areas were also identified by visual and count for its number inside the area. Apart from vegetation, all organisms, including insects, birds, and mammals found inside established plots, were recorded.

\subsection{Ecophysiological Attributes}

In dealing with the growth of host plant and agarwood potential occurrences, abiotic characteristics such as soil composition and nutrient content the relative humidity, temperature, and light intensity are pivotal factors to be known. Soil samples were obtained from the experimental plots in three research sites by digging up about $10 \mathrm{~cm}$ from the soil surface. The soil 
samples were then put inside a plastic bag and labeled for laboratory analysis. The total nitrogen of the soil was analyzed by the Kjeldahl method which goes through three stages, namely the process of destruction, distillation, and titration. The percentage of C-Organic in soil was analyzed using Walky and Black method, while the soil cation exchange capacity (CEC) was analyzed using the Atomic Absorption Spectrophotometry (AAS) method. A thermohygrometer was applied inside the established plots to obtain relative humidity and temperature recorded three times a day (morning, noon, and afternoon) for one week. Light intensity was measured in three research sites at noon using the Lux meter (BSN 2004).

\subsection{Agarwood Identification}

The identification of agarwood establishment in the host plant was carried out based on morphological characteristics through thoroughly visualized observation. In detail, further examination focused on the shape of a wound (either caused by insects or artificial wounds done by various triggers) (Mangold 1997). Established wounds were measured for their diameter using a mini caliper four times to obtain an average measurement. Tree damage symptoms and signs were evaluated according to the Forest Health Monitoring method, which was distinguished by codes (Mangold 1997). These codes started from 0-9, in which each number represented the status and characteristics of the host plant with agarwood infection. The wound that leads to damage and the type of damages were then identified and numerically classified based on the contribution of significant degradation ranging from 01-31 (Abimanyu et al. 2019; Mangold 1997).

\subsection{Data Analysis}

The agarwood infection and host tree found in this study were subjected to detailed description and identification, including flora and fauna associated with the host trees in the established plots. The most associated tree species as an indicator has been determined to predict the potential establishment of agarwood production in its hosted plant. Analysis of variance (ANOVA) was performed to understand the relationship among temperature, relative humidity, light intensity, and soil cation exchange capacity among the three research sites. Statistical analysis was performed using the R statistical program (Version R-3.6.2).

\section{Results and Discussion}

\subsection{Results}

\subsubsection{Tree host characteristics}

Agarwood producing trees are found in Teluk Wondama, Teluk Bintuni, and Manokwari. Places of growth and association with other plants, insects, and animals are presented in Table 1. Agarwood-producing trees are damaged both naturally and as a result of human activity. The damage that occurs to agarwood-producing trees is shown in Table 2.

The result noticed two agarwood-producing species in each study location. These two species were Gyrinops caudate and Aquilaria sp. found at an altitude of 167.7-402 masl. In terms of association rate over three research sites, it can be seen that there were forest vegetation, insects, and other animals found inside those established plots in the three research sites. The most associated forest tree in three research sites was Intsia bijuga and Endospermum malaccense found 
in all three research sites. The potential agarwood-producing species were generally situated in the old secondary forest with a moderate density of forest structure and composition. Whereas the most associated insects found were Camponotus pennsylvanicus, Argiope sp., Solenopsis sp., and Isoptera. In addition, lizards, as well as birds, were also confirmed over three research sites.

Table 1. Places of growth of agarwood trees and association with other plants, insects, and animals in Teluk Wondama, Teluk Bintuni, and Manokwari

\begin{tabular}{llll}
\hline \multicolumn{1}{c}{ Observed variable } & \multicolumn{1}{c}{ Teluk Wondama } & \multicolumn{1}{c}{ Teluk Bintuni } & \multicolumn{1}{c}{ Manokwari } \\
\hline Genus & Gyrinops caudate & Gyrinops caudate & Gyrinops caudate \\
& Aquilaria sp. & & \\
Altitude (masl) & $200-300$ & 167.7 & $400-402$ \\
Association with & & & \\
Plants & Intsia bijuga & Intsia bijuga & Intsia bijuga \\
& Endospermum & Endospermum & Endospermum \\
& malaccense & malaccense & malaccense \\
& Calamus spp. & Pteridophyta spp. & Pandanus spp. \\
& Pteridium sp. & Pandanus spp & Vatica papuana \\
& Dryopteris filix & Nepentes sp. & Pometia coriacea \\
& Asplenium nidus & Phothos rumpii & Swietenia macrophylla \\
& Vatica sp. & Philodendron sp. & Piper sp. \\
& Pometia pinata & Pteridium sp. & Vatica spp. \\
& Pometia coriacea & Calamus spp. & Calamus spp. \\
& Piper spp. & Pandanus spp. & \\
& Camponotus & Loranthus sp. & Camponotus \\
& pennsylvanicus & pennsylvanicus & pennsylvanicus \\
& Argiope sp. & Argiope sp. & Argiope sp. \\
& Solenopsis sp. & Solenopsis sp. & Solenopsis sp. \\
& Isoptera & Isoptera & Isoptera \\
& Lizard & Lizard & Lizard \\
& Bird & Bird & Bird \\
& &
\end{tabular}

Table 2. The damage occured on agarwood-producing trees

\begin{tabular}{lccc}
\hline Location & Observation plot & Agarwood tree & $\begin{array}{c}\text { Average wound area } \\
(\mathbf{c m})\end{array}$ \\
\hline Teluk Wondama & Plot 1 & Tree 1 & 1.13 \\
& & Tree 2 & 0.74 \\
& Plot 2 & Tree 1 & 0.71 \\
Teluk Bintuni & \multirow{3}{*}{ Plot 1 } & Tree 2 & 0.21 \\
& \multirow{3}{*}{ Plot 2 } & Tree 1 & 3.94 \\
& & Tree 2 & 2.56 \\
Manokwari & Plot 1 & Tree 1 & 3.11 \\
& & Tree 2 & 2.80 \\
& \multirow{2}{*}{ Plot 2 } & Tree 1 & 34.28 \\
& & Tree 2 & 2.49 \\
& & Tree 1 & 4.33 \\
& & Tree 2 & 6.34 \\
\hline
\end{tabular}

Based on disturbance characteristics of host trees, damage of agarwood production tree in the three research sites were open wound and termite attack. Most of the disturbances were open wounds, with the average number of wounds being 3 per host tree. Host trees infected by fungi 
have a diameter range from 11.1-34.4 cm with a maximum free branch height of $12 \mathrm{~m}$. Dominant wounds occurred close to the forest floor ( $<$ than $1.26 \mathrm{~m}$ up in height from the forest floor).

\subsubsection{Soil attributes}

Soil chemical characteristics have been found slightly different over three research sites. As presented in Fig. 2d, cation exchange capacity was higher in Manokwari $(24.77 \mathrm{cmol} / \mathrm{kg})$ compared to Teluk Bintuni $(11.42 \mathrm{cmol} / \mathrm{kg})$ and Teluk Wondama $(16.06 \mathrm{cmol} / \mathrm{kg})$. In addition, total C-organic analysis indicated the highest was found in Teluk Wondama (5.04\%), followed by Manokwari (4.02\%) and Teluk Bintuni (3.42\%). Total C-organic content in Teluk Wondama, Teluk Bintuni, and Manokwari are classified as high category. While the total-N contained had a slightly varied among three locations, where the highest was in Manokwari with an average of $0,43 \%$, then followed by Teluk Wondama by $0.37 \%$ and the lowest was in Teluk Bintuni with only $0.27 \%$. Total N content in Teluk Wondama, Teluk Bintuni, and Manokwari are classified as moderate category.

(a)

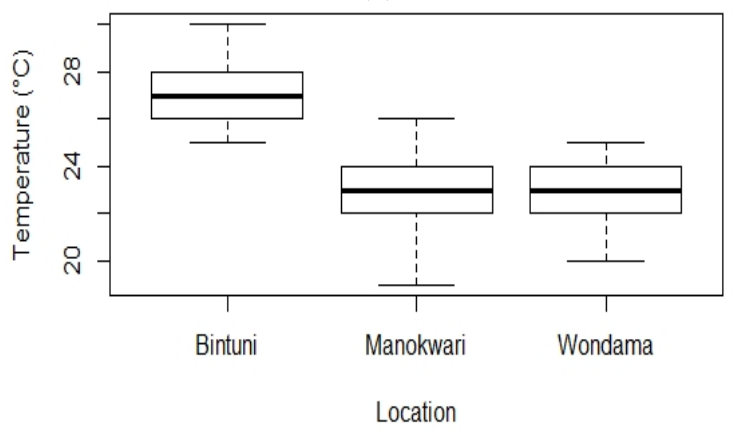

(c)

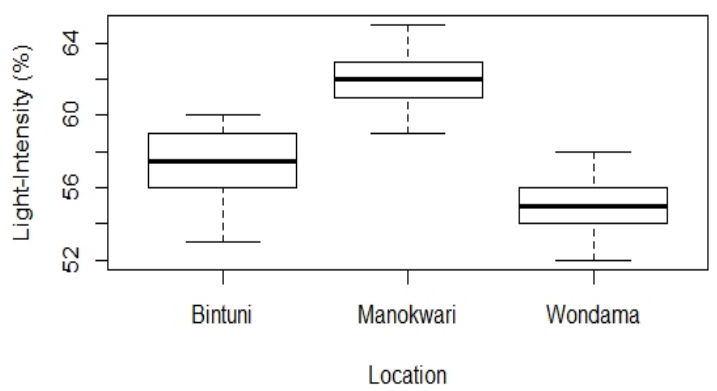

(b)

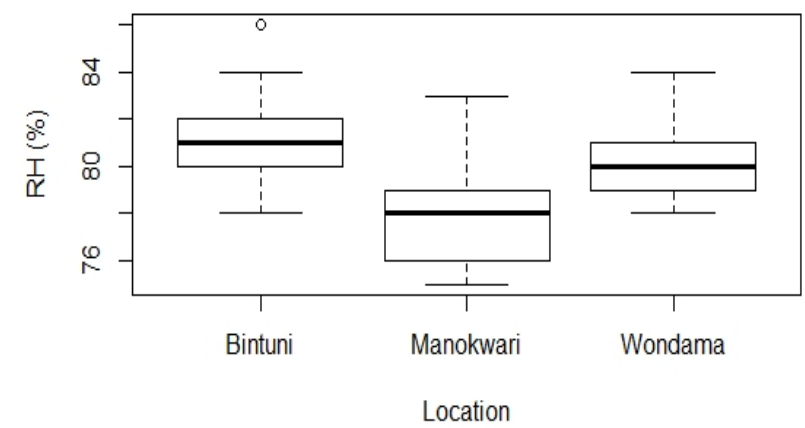

(d)

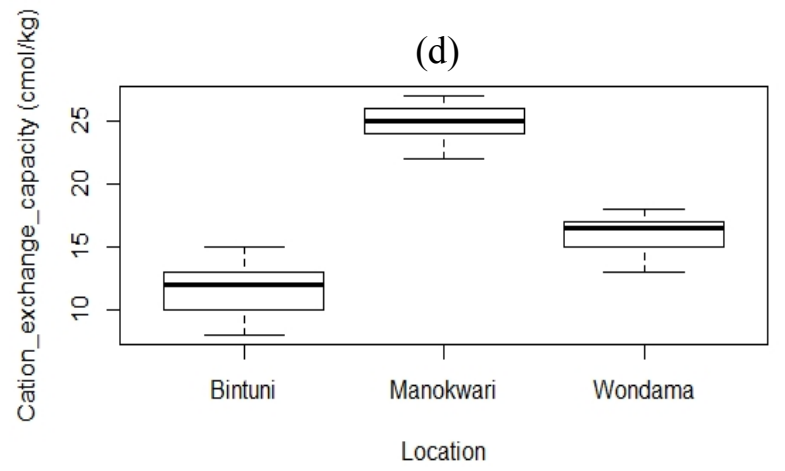

Fig. 2. The ecophysiological and soil attributes in the research sites: (a) temperature $\left({ }^{\circ} \mathrm{C}\right),(\mathrm{b})$ relative humidity $(\%)$, (c) light intensity $(\%)$, and (d) cation exchange capacity (cmol/kg).

\subsection{Discussion}

Based on the study, potential agarwood has been found dominant in Gyrinops caudate as a suitable host over three research sites. The damage on agarwood-producing trees is generally an open wound. The fungus can use the open wound on the trunk as an entrance to the plant tissues. There are several potentially hosted plants to be infected by the fungus to generate potential agarwood. However, it has been widely known that the most tree species to become hosts are from Aquilaria and Gyrinops genus. As an endemically tropical plant, both genera have been widespread across the Pacific up to South Asia, including India, Bangladesh, and Pakistan 
(Whitmore 1972). The wide distribution of the genus was likely to be hosted by the preferred fungus to develop agarwood products. Both genus are common to discover in Indonesia from Sumatera up to Guinea Island in the east, including in few small islands. However, in terms of the suitable habitat and distribution, there is an indication that Gyrinops is likely to be more widely distributed in the eastern region of Indonesia started from East Nusa Tenggara and most locations in West Papua province up to Papua New Guinea (Rindyastuti et al. 2019). Hou (1960) highlighted that most of the Gyrinops have only been distributed in east Indonesia. Moreover, In West Papua, the distribution of G. caudate has been reported mostly in the south region, such as Merauke, Agats, Mappi, and Boven Digoel (Mulyaningsih and Yamada 2007).

In terms of an altitudinal range of the agarwood producing species distribution, it has been noticed that all the agarwood-producing species plant was distributed in the lowland areas with less than 1,000 masl. Lowland areas across tropical regions have been known for their high rate of tree distribution, dense structure combined with a complex forest ecosystem which is turned out to be an ideal habitat to uphold tree growth and development (Amazonas et al. 2018; Gallery 2014). This study indicated that all agarwood-producing trees had been distributed in the lowland area with less than 450 masl. G. caudate has been found distributed in the lowland tropical forest with a slightly disturbed condition in which suitable to the species for growing and development (Indonesian Institute of Science 2014). Soil characteristics indicated that all three research sites have been made up of dominant sandy loam soil and had a record of temporary inundating when over rainfall occurs. Mulyaningsih and Yamada (2007) noticed that G. Caudate distributed in the south of West Papua ideally grew in the common soil type of sandy clay. Even though slight variation was noticed, there was no significance for temperature and relative humidity from these three research sites (Fig. 2b). Light intensity is also designated with no significant differences among the three research sites (Fig. 2c). Agarwood has been found suitably growing at the ranging temperature from 14 to $28{ }^{\circ} \mathrm{C}$ (Oyen and Dung 1999). Tree growth is determined by the quality of the place where it grows (Artika et al. 2015).

G. caudate as potential agarwood-producing species found in the research sites was a relatively young tree, as can be seen from the diameter range $(11.1 \mathrm{~cm}-32.8 \mathrm{~cm})$. Based on the G. caudate tree characteristics reported by Mulyaningsih and Yamada (2007), the maximum diameter could reach $36 \mathrm{~cm}$, with the total height of $17 \mathrm{~m}$. Due to these characteristics, the species has been categorized as a tree. It seemed that the likelihood of agarwood to occur was in the relatively young tree with the age range from five to twenty years, as noticed by Farida-Hanum et al. (2009). Rindyastuti et al. (2019) pointed out that another Gyrinops versteegii that grow in the Lombok region potentially produce agarwood with a mean diameter of $29.35 \mathrm{~cm}$. Chowdhury et al. (2017) noticed the ideal agarwood-producing species to be purposively wounded by fungus infection for agarwood was at 8 or 9 years old with the diameter range between $15-19 \mathrm{~cm}$. Based on the result found in Manokwari, Teluk Bintuni and Teluk Wondama, it was noticed that wound in hosted plants has been an initiation in order to stimulate agarwood production through the fungal infection process. These wounds have been seen in the bottom part of the hosted plants. However, a few cases used the trunk as an initiating media for infecting wood (Chen et al. 2018). Agarwood can be spread across all parts of the tree from the transfusion point in the truck to all branches and the root system. Tree wounding has been one of the prominent pathways in generating agarwood production, and various methods have been known for wounding trees (Liu et al. 2013).

During the initial infectious process by fungi and potentially related insects, an underlying factor underpins the process. The most indicator to be concerned was an association in the growing 
habitat of agarwood-producing trees. Tree association in the ecosystem will generate either potential development of fungus or vise versa, leading to the inhibiting agent. Some studies found the process of agarwood in the hosted tree was on account of stress adaptability when the surrounding environment was unbalanced, which led to under stress (Novriyanti and Santoso 2011). Endospermum malaccense and Intsia Bijuga had a very close association to agarwoodproducing trees over three research sites that mean as a key indicator to these species. From the ecological viewpoint, these two species are potentially rendered a suitable niche for hosted plants and likely trigger fungus and insects to stay and attack wounded stems. Besides, these two tree species have been endemic that can be found in the lowland tropical rainforest of West Papua with a large tree characteristic. In addition to insect association with agarwood-producing trees, the common insects found were Camponotus pennsylvanicus, Solenopsis sp., and Argiope sp., over three research sites. As agarwood produces specific chemical compounds and exudates resin, these natural products then entice these insects. Several birds are also discovered around potential agarwood-producing trees, and these birds are likely looking for fruit produced by the tree. Based on a previous report (Indonesian Institute of Sciences 2014), for Aquilaria and Gyrinops species in Sumatera, several potential birds have been seen eating their seeds, and the larva of beetles ate the wood.

\section{Conclusions}

Three research sites in Teluk Wondama, Teluk Bintuni, and Manokwari have been selected to assess the ideal ecosystem for agarwood-producing trees in the West Papua forests. The results indicated that the species-specific tree and insect association are needed to be acknowledged for the development of agarwood-producing habitats in the lowland tropical rainforest of West Papua. Noticing ideal habitats and their association is fundamental for the future development of agarwood plantations in West Papua.

\section{Acknowledgments}

The authors appreciate the financial support from the Indonesia Endowment Fund for Education (LPDP) and the Graduate Program of Forestry Science, Faculty of Forestry, Gadjah Mada University for an opportunity given to the author. Countless thanks are also presented to local governments for their field assistantship.

\section{References}

Abimanyu, B., Safe'i, R., and Hidayat, W. 2019. Application of Forest Health Monitoring Method in Assessing Tree Damage in Metro Urban Forests. Jurnal Sylva Lestari 7(3): 289-298. DOI: 10.23960/js137289-298

Amazonas, N. T., Viana, R. A. G., Rego, M. G. A., Camargo, F. F., Fujihara, R. T., and Valsechi, O. A. 2018. Soil Macrofauna Density and Diversity Across a Chronosequence of Tropical Forest Restoration in Southeastern Brazil. Brazil Journal of Biology 78 (3): 449-456. DOI: 10.1590/1519-6984.169014 
Artika, E., Duryat, and Herwanti, S. 2015. Identification and Mapping of Plus Palm Sugar Plant (Arenga pinnata) in the Integration Conservation Education Forest at Great Forest Wan Abdul Rachman. Jurnal Sylva Lestari 3(1): 41-50. DOI: 10.23960/js11341-50

BSN. 2004. Pengukuran intnesitas penerangan di tempat kerja. SNI 16-7062-2004. Badan Standarisasi Nasional (BSN).

Chen, X., Liu, Y., Yang, Y., Feng, J., Liu, P., Sui, C., and Wei, J. 2018. Trunk Surface AgarwoodInducing Technique with Rigidoporus vinctus: An Efficient Novel Method for Agarwood Production. PLOS ONE 13(6): 1-13. DOI: 10.1371/journal.pone.0198111

Chowdhury, M., Rahman, A., Hussain, M. D., and Kabir, E. 2017. The Economic Benefit of Agarwood Production through Aeration Method into the Aquilaria malaccensis Tree in Bangladesh. Bangladesh Journal of Agricultural Research 42(1): 191-196. DOI:10.3329/bjar.v42i1.31992

Farida-Hanum, I., Mustapa, M. Z., Lepun, P., Marina, T. I. T., Nazre, M., Alan, R., and Mohamad, R. 2009. Notes on the Distribution and Ecology of Aquilaria Lam. (Thymelaceae) in Malaysia. The Malaysian Forester 72(2): 247-259.

Gallery, R. E. 2014. Ecology of Tropical Rain Forests. In: Ecology and Environment. Springer. New York. DOI: 10.1007/978-1-4614-7501-9_4

Holopainen, J. K., Virjamo, V., Ghimre, R. P., Blande, J. D., Julkulen-Titto, R., and Kivimãenpãã, M. 2018. Climate Change Effects on Secondary Compounds of Forest Trees in the Northern Hemisphere. Frontiers in Plant Science 9(1445): 1-10. DOI: 10.3389/fpls.2018.01445

Hou, D. 1960. Thymiliaceae. In: Flora Malesiana Series I. Vol 6. Wolter-Noordholf PublishingGroningen, Netherlands.

Indonesian Institute of Sciences. 2014. Report on NDF of Agarwood for Sustainability Harvest in Indonesia. Research Center for Biology, Indonesian Institute of Sciences and Director General of Forest Protection and Nature Conservation, Forestry Department.

Irvantia, W., Indriyanto, and Riniarti, M. 2014. The Effect of Number of Branch Internodes on Black Bamboo (Giganthochloa atroviolacea) Cutting Growth. Jurnal Sylva Lestari 2(1): 5966. DOI: $10.23960 /$ js11259-66

Lekitoo, K., Peday, H. F. Z., Panambe, N., and Cabuy, R. L. 2017. Ecological and Ethnobotanical Facet of 'Kelapa Hutan' (Pandanus spp.) and Perspectives towards Its Existence and Benefit. International Journal of Botany 13(3): 103-114. DOI: 10.3923/ijb.2017.103.114

Liu, Y., Chen, H., Yang, Y., Zhang, Z., Wei, J., Meng, H., Chen, W., Feng, J., Gan, B., Chen, X., Gao, Z., Huang, J., Chen, B., and Chen, H. 2013. Whole-Tree Agarwood-Inducing Technique: An Efficient Novel Technique for Producing High-Quality Agarwood in Cultivated Aquilaria sinensis Trees. Molecules 18(3): 3086-3106. DOI: 10.3390/molecules 18033086

Mangold, R. 1997. Forest Health Monitoring: Field Methods Guide. (USDA, ed.) USDA Forest Service, USA.

Nasi, R., and Frost, P. G. H. 2009. Sustainable Forest Management in the Tropics: Is Everything on Order but the Patient Still Dying?. Ecology and Society 14(2): 40. DOI: 10.5751/es03283-140240

Nguyen, T. V., Mitlohner, R., Bich, N. V., and Do, T. V. 2015. Environmental Factors Affecting the Abundance and Presence of Tree Species in a Tropical Lowland Limestone and NonLimestone Forest in Ben En National Park, Vietnam. Journal of Forest and Environmental Science 31(3): 177-191. DOI: 10.7747/jfes.2015.31.3.177 
Novriyanti, E., and Santoso, E. 2011. The Role of Phenolics in Agarwood Formation of Aquilaria crassna Pierre ex Lecomte and Aquilaria microcarpa Baill Trees. Journal of Forestry Research 8 (2): 101-113. DOI: 10.20886/ijfr.2011.8.2.101-113

Oyen, L. P. A., and Dung, N. X. 1999. Plant Resources of South-East Asia No. 19 Essential - Oil Plants. Backhuys Publishers Leiden. The Netherlands.

Rindyastuti, R., Yulistyarini, T., and Darmayanti, A. Y. 2019. Population and Ecological Study of Agarwood Producing Tree (Gyrinops versteegii) in Manggarai District, Flores Island, Indonesia. Biodiversitas 20(4): 1180-1191. DOI: 10.13057/biodiv/d200434

Sampaio, B. L., Edrada-Ebel, R., and Da Costa, B. D. 2016. Effect of the Environment on the Secondary Metabolic Profile of Tithonia diversifolia: A Model for Environmental Metabolomics of Plants. Scientific Reports 6:29265. DOI: 10.1038/srep29265

Sayfulloh, A., Riniarti, M., and Santoso, T. 2020. Invasive Alien Species Plants in Sukaraja Atas Resort, Bukit Barisan Selatan National Park. Jurnal Sylva Lestari 8(1) :109-120. DOI: 10.23960/js118109-120

Subasinghe, S.M., and Hettiarachchi, D.S. 2015. Characterisation of Agarwood Type Resin of Gyrinops walla Gaertrn Growing in Selected Population in Sri Langka. Industrial Crops and Product 69: 76-79. DOI: 10.1016/j.indcrop.2015.01.060

Tuck, S. L., O’Brien, M. J., Philipson, C. D., Saner, P., Tanadini, M., Dzulkifli, D., Godfray, H. C. J., Godoong, E., Nilus, R., Ong, R., Schimd, B., Sinun, W., Snaddon, J. L., Snoep, M., Tangki, H., Tay, J., Ulok, P., Wai, Y. S., Weilenmann, M., Reynolds, G., and Hector, A. 2016. The Value of Biodiversity for the Functioning of Tropical Forests: Insurance Effects during the First Decade of the Sabah Biodiversity Experiment. Proceedings of the Royal Society B: Biological Sciences 283(1844): 20161451. DOI: 10.1098/rspb.2016.1451

Whitmore, T. C. 1972. Tree Flora of Malaya: A Manual of Foresters, Vol. 2 Longman. Kuala Lumpur. Malaysia.

Yang, L., Wen, K. S., Ruan, X., Zhao, Y. X., Wei, F., and Wang, Q. 2018. Response of Plant Secondary Metabolites to Environmental Factors. Molecules 23(4): 762 DOI: 10.3390/molecules23040762

Yuliasyah, Siran, S. A., Kholik, A., and Rayan, M. R. 2003. Gaharu Komoditi HHBK Andalan Kalimantan Timur. Balai Penelitian dan Pengembangan Kehutanan Kalimantan. 